\title{
PENGEMBANGAN LKPD INKUIRI BERBASIS HANDS-ON \& MINDS-ON ACTIVITY UNTUK MENINGKATKAN HOTS PADA MATERI LAJU REAKSI
}

\section{DEVELOPMENT OF INQUIRY STUDENT WORKSHEET BASED ON HANDS-ON \& MINDS-ON ACTIVITY TO IMPROVE HIGHER ORDER THINKING SKILL STUDENTS IN REACTION RATES}

\author{
Ikke Ladya Khafida dan *Ismono \\ Jurusan Kimia FMIPA Universitas Negeri Surabaya \\ e-mail: ismono@unesa.ac.id
}

\begin{abstract}
Abstrak
Penelitian ini memiliki tujuan untuk mengetahui kelayakan Lembar Kerja Peserta Didik (LKPD) inkuiri terbimbing berbasis hands-on \& minds-on activity untuk melatihkan Keterampilan Berpikir Tingkat Tinggi (HOTS) pada materi Laju Reaksi. Kelayakan LKPD berpedoman pada validitas, kepraktisan, dan keefektifan. Desain penelitian yang digunakan dalam penelitian ini adalah 4D (define, design, develop, dissiminate), dan pada penelitian ini tahap yang digunakan hanya sampai tahap develop (pengembangan) dengan uji coba terbatas kepada 12 peserta didik kelas XI-IPA-5 di sebuah SMAN Sidoarjo yang belum mendapatkan topik belajar Laju Reaksi. Instrumen penelitian yang digunakan meliputi lembar telaah, lembar validasi, lembar angket respon, lembar tes ranah pengetahuan, dan lembar tes HOTS. Instrumen penelitian tersebut dianalisis menggunakan metode deskriptif kuantitatif. Hasil validasi berdasarkan kelayakan kriteria isi, kebahasaan, penyajian, dan kegrafisan menunjukkan persentase berturut-turut sebesar $83 \%, 82 \%, 82 \%$, dan $83 \%$ dengan kategori sangat valid. Respon peserta didik menunjukkan persentase yang cukup tinggi dengan rata-rata $90,7 \%$ yang menunjukkan sangat praktis. Hasil tes pengetahuan memperoleh ketuntasan klasikal sebesar $100 \%$ dengan kategori tuntas sedangkan untuk peningkatan HOTS mendapat skor $\mathrm{N}$-gain rata-rata 0,73 dengan kategori tinggi, dimana setiap komponen HOTS C4,C5, dan C6 didapatkan rata-rata persentase secara berturut-turut sebesar 86,8\%, 83,3\%,dan 87,5\% sehingga dapat diartikan LKPD efektif untuk meningkatkan HOTS peserta didik.

Kata kunci: LKPD, Inkuiri, Keterampilan Berpikir Tingkat Tinggi, Hands on Minds on Activity.
\end{abstract}

\begin{abstract}
The research aims to determine the feasibility of Guided Inquiry Student Worksheet based on hands-on \& minds-on activity to improve HOTS in reaction rates subject. Feasibility of Student Worksheet is guided by validity, practicality, and effectiveness. The design of development research uses the 4-D method (Define, Design, Develop, Dissiminate) and in this research just until development stage with the limited trial which conducted on 12 students of class XI-IPA-5 in a SMAN Sidoarjo who had not yet receive the reaction rates subject. The research instruments consist of review sheets, validation sheets, student response questionnaire sheets, knowledge test sheets and higher order thinking skills test sheets. Analysis of data uses quantitative dexcriptive methods. The validator assessment based on the feasibility of content criteria language, presentation, and graphic that show a percentage of $83 \%, 82 \%, 82 \%$, and $83 \%$ in the very valid category. Student responses show the high percentage namely the average 90,7\% in the practical category. The result of knowledge test supported by classical completeness get a percentage of $100 \%$ in the complete category, while the improvement of HOTS received on N-gain score of 0,73 in the high category, which is component of higher order thinking skills for categories C4,C5, and C6 get an average of 86,8\%,83,3\%,dan 87,5\%, so that can be interpreted that student worksheet effective for increasing HOTS of student.
\end{abstract}

Key words: Student Worksheet, Guided Inquiry, higher order thinking skill, Hands on Minds on Activity. 


\section{PENDAHULUAN}

Pendidikan adalah salah satu cara yang paling penting dan mendasar guna mencetak sumber daya manusia yang unggul agar nantinya dapat siap bersaing di abad ke-21. Pada abad ke-21 peserta didik harus mampu menguasai berbagai keilmuan, memiliki keterampilan metakognitif, dapat berpikir kritis dan kreatif, serta mampu berkomunikasi atau berkolaborasi dengan efektif [1].

Data PISA tahun 2018 menunjukkan bahwa nilai rata-rata sains dan matematika Indonesia menempati peringkat 72 dari 77 negara yang berpartisipasi [2]. Dalam peringkat tersebut dapat disimpulkan bahwa kemampuan peserta didik Indonesia dalam bidang sains dan matematika terbilang rendah. Sebagai upaya untuk meningkatkan kemampuan tersebut pemerintah Indonesia telah menyiapkan berbagai upaya diantaranya adalah penyediaan sumber daya yang mendukung, program pelatihan guru, penyedian sarapras, serta pembaharuan kurikulum [3]. Kurikulum memegang peranan yang sangat penting terhadap kemajuan pendidikan di Indonesia, sehingga pelaksanaannya harus benarbenar dioptimalkan.

Kurikulum yang paling terbaru saat ini adalah kurikulum 2013. Kurikulum 2013 dikenal sebagai pembelajaran yang berpusat kepada peserta didik, kurikulum 2013 menuntut keaktifan guru dalam pengimplementasian proses pembelajaran yang otentik, bermakna, dan menantang dengan cara melibatkan secara aktif para peserta didik dalam pembelajaran agar potensi peserta didik dapat dikembangkan berdasarkan apa yang diinginkan oleh tujuan pendidikan nasional [4].

Pengoptimalan pelaksanaan kurikulum 2013 ini memerlukan keterampilan berpikir yang mendukung dan sesuai, dimana menurut Brookhart (2010) [5] HOTS (High Order Thinking Skills) peserta didik dapat digunakan untuk mengatasi masalah yang ada dengan pemikiran analitis sehingga memiliki dampak pada kemampuan pemecahan masalah peserta didik seperti tuntunan dari kurikulum 2013. HOTS merupakan kemampuan berpikir yang meliputi berpikir logis, kritis, metakognitif reflektif, dan kreatif. Berdasarkan teori taksonomi Bloom revisi, keterampilan berpikir tingkat tinggi merupakan keterampilan yang paling abstrak dalam domain kognitif, yaitu analisis (C4), mengevaluasi (C5), serta mencipta (C6) yang meliputi membuat hipotesis, dan mengemukakan ide/gagasan [6].

Bidang ilmu yang mewadahi terlaksananya kurikulum 2013 salah satunya adalah ilmu kimia, hal ini didukung dengan data PISA yang menyatakan bahwa kemampuan matematika dan sains Indonesia terbilang cukup rendah. Ilmu kimia adalah bagian dari ilmu science yang dikembangkan serta diperoleh menurut data eksperimen untuk mencari jawaban mengenai pertanyaan yang ada seperti apa, mengapa, dan bagaimana gejala-gejala alam khususnya yang berkaitan dengan komposisi, sifat, transformasi struktur, dinamika, dan energitika zat [7]. Kompetensi dasar yang diperuntukkan untuk materi laju adalah KD 3.4 Menjelaskan faktorfaktor yang mepengaruhi laju reaksi menggunakan teori tumbukan dan 4.5 Merancang, melakukan dan menyimpulkan serta menyajikan hasil percobaan faktor-faktor yang mempengaruhi laju reaksi dan orde reaksi [8].

HOTS dalam ilmu Laju Reaksi dapat ditingkatkan melalui model pembelajaran inkuiri. Hal tersebut dikarenakan model pembelajaran inkuiri membutuhkan suatu penyelidikan untuk menemukan jawaban sendiri sehingga dimunculkanlah praktikum atau percobaan yang berfungsi untuk memperkuat konsep dan sikap analisis yang berorientasi pada keterampilan berpikir tingkat tinggi. Selain itu, pembelajaran inkuiri juga tidak hanya menuntut peserta didik untuk mengetahui, memahami, dan mengaplikasikan saja tetapi juga mampu menganalisis, mengevaluasi, serta mencipta dimana hal tersebut selaras dengan keterampilan berpikir tingkat tinggi [6]. Adanya kolaborasi antara HOTS dan model pembelajaran inkuiri pada mata pelajaran sains khususnya kimia ini diharapkan dapat membantu Indonesia untuk meraih peringkat yang lebih tinggi dalam kategori nilai rata-rata kemampuan matematika dan sains dalam data PISA 2018. 
Kegiatan praktikum dapat dimaksimalkan dengan pemahaman konsep secara teoritis dimana dibutuhkan kolaborasi yang sinergis antara aktivitas psikis (intelektual) dan aktivitas fisik (keterampilan tangan) pada saat praktikum dilakukan. Hal ini dapat kita sebut sebagai handson \& minds-on activity. Hands-on \& minds-on activity akan memberikan pemahaman secara mendalam terhadap apa yang dipelajari, sehingga apa yang diperoleh oleh peserta didik tidak mudah dilupakan. Minds on activity meliputi segala aspek yang memfokuskan peserta didik untuk membangun konsepnya sendiri seperti mengamati, menulis, mengajukan pertanyaan, menegosiasi, serta mengomunikasikan. Sedangkan Hands on activity disini meliputi kegiatan yang melibatkan peserta didik dalam menggali pengetahuannya sendiri seperti bertanya, mengumpulkan data dan menganlisis, serta memberikan kesimpulan [9].

Pemberian bahan ajar dengan model inkuiri terbimbing berbasis Hands on activity \& Minds on activity untuk melatihkan HOTS ini sangat diperlukan guna memetakan seluruh aktivitas selama proses pembelajaran, terutama di masa pandemic seperti ini dimana proses belajar belajar dan mengajar tidak dapat terlaksana secara maksimal. Pembelajaran selama pandemic ini menggunakan system pembelajaran secara online. Moore et al menyatakan bahwa pembelajaran online adalah segala kegiatan pembelajaran yang membutuhkan jaringan internet dengan konektivitas, aksesibilitas, fleksibilitas, serta kemampuan untuk memunculkan berbagai jenis interaksi pembelajaran [10]. Dalam pembelajaran online yang sangat bergantung pada hal-hal tersebut tentunya akan terdapat lebih banyak kendala jika dibandngkan dengan sekolah offline yang langsung bertatap muka antara guru dan peserta didiknya.

Guna memaksimalkan proses belajar peserta didik dirumah dipilihlah LKPD sebagai bahan ajar yang dapat memandu aktivitas belajar peserta didik serta dapat menunjang tujuan pembelajaran kurikulum 2013 itu sendiri. Menurut penjelasan depdiknas (2008) penggunaan LKPD dapat mempermudah guru selama proses belajar mengajar, sehingga dapat membiasakan peserta didik untuk belajar secara aktif dan mandiri serta menjalankan tugas secara tertulis [11]. Hal ini didukung oleh penelitian Aulia, (2015) [12] dimana LKPD yang dikembangkan dengan model inkuiri terbimbing dapat dikatakan efektif untuk meningkatkan keterampilan berpikir tingkat tinggi. Hal ini dibuktikan dengan nilai rata-rata $n$-gain yang didapatkan sebesar 0,66 yang termasuk dalam kategori cukup. Penlitian kedua yang mendukung kolaborasi antara hands-on \& minds-on activity dengan inkuiri terbimbing adalah penelitian Kurniawan, (2017) yang mengatakan bahwa didapatkan hasil yang positif serta signifikan antara hands-on \& minds-on activity terhadap hasil belajar peserta didik ranah pengetahuan melalui model pembelajaran inkuiri terbimbing. Persentase pengaruh hands on minds on activity terhadap hasil belajar peserta didik dalam ranah kognitif melalui inkuiri terbimbing sebesar 64,5\% [9].

Hasil pra penelitian di SMAN 1 Krian menunjukkan bahwa pada proses pembelajaran telah digunakan LKPD dan sebanyak 86,7\% peserta didik merasa bahwa penggunaan LKPD dirasa sangat membantu dalam memahami pembelajaran. Namun berdasarkan hasil wawancara dengan guru LKPD yang digunakan di SMAN 1 Krian hanya berisi materi dan soal-soal, masih belum pernah menggunakan LKPD dengan model pembelajaran inkuiri dengan menerapkan keterampilan berpikir tingkat tinggi, cara penyampain yang digunakan pun masih menggunakan metode ceramah sehingga peserta didik belum dilibatkan secara aktif dalam proses pemecahan masalah yang mengkolaborasikan aktivitas tangan dan pikiran. Hal tersebut dibuktikan dengan hasil Pre-Test peserta didik SMAN 1 Krian dimana rata-rata yang didapatkan adalah sebesar 52,7 untuk ranah keterampilan berpikir tingkat tinggi pada materi laju reaksi, dimana hal ini sangat jauh dari rata-rata KKM yang ditetapkan disekolah sehingga penting untuk melatihkan keterampilan HOTS di SMAN 1 Krian agar hasil belajar peserta didik dapat lebih baik dari sebelumnya.

Ditinjau dari latar belakang yang telah dipaparkan, maka dikembangkan LKPD inkuiri terbimbing berbasis Hands-on \& minds-on activity 
untuk melatihkan HOTS. Sebagai solusi agar peserta didik dapat lebih mudah dalam memahami konsep sehingga mencapai kategori ketuntasan belajar yang ditetapkan di sekolah serta keterampilan berpikir tingginya dapat terlatihkan.

\section{METODE}

Penelitian ini dikembangkan dengan metode 4-D yang dirancang oleh Thiagarajan [13]. Tahapan proses penelitian dari metode 4-D ini meliputi define (pendefinisian), design (perancangan), develop (pengembangan), dan deseminate (penyebaran), akan tetapi pada penelitian ini tahap yang digunakan hanya sampai tahap develop (pengembangan) dengan proses uji coba terbatas. Kelayakan LKPD yang dikembangkan pada penelitian ini berpedoman pada validitas, kepraktisan, dan keefektifan [14].

Data penelitian yang didapatkan dari pengembangan LKPD ini berasal dari hasil telaah, validasi, dan data hasil uji coba terbatas. Pengujian terbatas ini dilakukan di kelas XI IPA 5 SMAN 1 Krian dengan jumlah responden (peserta didik) sebanyak 12 responden. Instrumen penelitian yang digunakan meliputi lembar telaah, lembar validasi LKPD, angket respon, lembar soal pretest dan posttest HOTS, serta lembar soal ranah pengetahuan.

Data hasil telaah dianalisis secara deskriptif kualitatif dimana datanya berupa hasil penilaian dan masukan dari ahli / pakar yang digunakan sebagai bahan perbaikan dari LKPD yang dikembangkan. Kemudian untuk hasil validasi dianalisis secara deskriptif kuantitatif yang berupa persentase. Persentase hasil validasi ini diperoleh dari skor kriteria penilaian dari skala Likert yang disajikan pada Tabel 1 berikut:

Tabel 1. Skor Skala Likert

\begin{tabular}{cc}
\hline Penilaian & Nilai Skala \\
\hline Sangat tidak sesuai & 1 \\
Kurang sesuai & 2 \\
Cukup sesuai & 3 \\
Sesuai & 4 \\
Sangat sesuai & 5 \\
\hline
\end{tabular}

Untuk menghitung persentase kelayakan LKPD, rumus yang digunakan adalah sebagai berikut (1):

$(\%)$ validitas $=\frac{\text { jumlah skor yang diperoleh }}{\text { skor kriteria }} \times 100 \%$

Skor Kriteria = skor maksimal x jumlah aspek yang dinilai $x$ jumlah responden

Kemudian, data hasil persentase tersebut diinterpretasikan dalam kriteria Tabel 2 berikut:

Tabel 2. Kriteria Interpretasi

\begin{tabular}{cc}
\hline Persentase (\%) & Kriteria \\
\hline $0-20$ & Sangat Ttidak valid \\
$21-40$ & Tidak valid \\
$41-60$ & Cukup valid \\
$61-80$ & Valid \\
$81-100$ & Sangat valid \\
\hline
\end{tabular}

Berdasarkan kriteria pada Tabel 2 diatas, LKPD yang dikembangkan dapat dikatakan memenuhi kriteria dan dapat dikatakan valid apabila skor persentase $\geq 61 \%$ sehingga nantinya dapat diujicobakan secara terbatas dalam proses pembelajaran.

Selanjutnya angket respon yang diisi oleh peserta didik dianalisis dimana awalnya dihasilkan persentase nilai kemudian disimpulkan dalam bentuk kalimat deskriptif. Persentase ini dihitung berdasarkan skala Guttman pada Tabel 3 berikut:

Tabel 3. Skala Guttman

\begin{tabular}{ccc}
\hline Pertanyaan & Jawaban & Skor \\
\hline \multirow{2}{*}{ Positif } & Ya & 1 \\
& Tidak & 0 \\
Negatif & Ya & 0 \\
& Tidak & 1
\end{tabular}

Selanjutnya, ntuk menghitung persentase kelayakan nilai angket respon, rumus yang digunakan adalah sebagai berikut:

(\%) respon $=\frac{\text { jumlah skor yang diperoleh }}{\text { skor kriteria }} \times 100 \%$

Kemudian persentase yang didapatkan tersebut diinterpretasikan dalam kriteria pada Tabel 4 berikut: 
Tabel 4. Interpretasi Skor Respon

\begin{tabular}{cc}
\hline Persentase (\%) & Penilaian \\
\hline $0-20$ & Sangat Ttidak merespon \\
$21-40$ & Tidak merespon \\
$41-60$ & Kurang merespon \\
$61-80$ & Merespon \\
$81-100$ & Sangat merespon \\
\hline
\end{tabular}

Hasil belajar ranah pengetahuan dapat dihitung menggunakan rumus sebagai berikut:

$$
\text { Hasil Belajar }=\frac{\text { jumlah skor yang diperoleh }}{\text { skor kriteria }} \times 100
$$

Berdasarkan perhitungan hasil belajar ranah kognitif tersebut nilai hasil belajar dapat dikatakan tuntas apabila sama atau lebih dari Ketuntasan Belajar Minimun $(\mathrm{KKM}) \geq 75$ sesuai dengan kebijakan nilai KKM yang berlaku di SMAN 1 Krian.

Analisis keterampilan berpikir tingkat tinggi individu didapatkan dari hasil pretest dan posttest. Data ini kemudian dianalisis secara deskriptif kuantitatif dengan perhitungan $n$-gain score $<\mathrm{g}>$ / selisih rata-rata dari nilai pretest dan posttest terhadap aspek C4, C5, dan C6 yang dihitung menggunakan rumus sebagai berikut:

$$
\begin{aligned}
& \text { (\%)HOTS }=\frac{\text { jumlah skor yang diperoleh }}{\text { skor maksimal }} \times 100 \% \\
& \text { Hasil yang diperoleh kemudian } \\
& \text { diintrepetasikan kedalam Tabel } 5 \text { berikut: }
\end{aligned}
$$

Tabel 5. Interpretasi Score

\begin{tabular}{cc}
\hline Persentase (\%) & Kategori \\
\hline $0-30$ & Sangat rendah \\
$31-54$ & Rendah \\
$55-74$ & Normal \\
$75-89$ & Tinggi \\
$90-100$ & Sangat tinggi \\
\hline
\end{tabular}

Berdasarkan Tabel 5, hasil tes HOTS dari setiap individu dianalisis menggunakan perhitungan $n$-gain-score $\langle\mathrm{g}\rangle$, menggunakan rumus berikut:

$$
<\text { g }>=\frac{\text { skor posttest }- \text { skor pretest }}{\text { skor maksimal }- \text { skor pretest }}
$$

Nilai n-gain-score yang didapat dari perhitungan tersebut kemudian diinterpretasikan pada Tabel 6 berikut:
Tabel 6. Kriteria n-gain score

\begin{tabular}{cc}
\hline Nilai & Kriteria \\
\hline $\mathrm{g} \geq 0,7$ & Tinggi \\
$0,3 \leq \mathrm{g} \geq 0,7$ & Sedang \\
$\mathrm{g} \leq 3$ & Rendah \\
\hline
\end{tabular}

Berdasarkan Tabel 6 tersebut dapat disimpulkan bahwa HOTS dikatakan terlatih apabila skor $n$-gain yang diperoleh $\geq 0,7$.

\section{HASIL DAN PEMBAHASAN}

Hasil dan Pembahasan ini berisi uraian rinci mengenai seluruh hasil penelitian beserta analisisnya. Hasil penelitian pengembangan LKPD ini memperoleh data-data sebagai berikut: hasil telaah dan validasi LKPD, persentase rata-rata nilai tes aspek pengetahuan, persentase rata-rata nilai tes HOTS, serta respon peserta didik terhadap LKPD yang dikembangkan.

Penelitian ini dikembangakan dengan metode 4D yang juga disesuaikan dengan pembelajaran online pada masa pandemi. Tahapan proses penelitian dari metode 4-D ini meliputi define (pendefinisian), design (perancangan), develop (pengembangan), dan deseminate (penyebaran), akan tetapi dalam penelitian ini tahap yang digunakan hanya sampai tahap develop (pengembangan) dengan proses uji coba terbatas [13].

\section{Tahap Define (Pendefinisian)}

Pada tahap ini berisi analisis kebutuhan, kompetensi, peserta didik, tugas, serta analisis konsep [17]. Hasil dari analisis ini merupakan rumusan dari tujuan pembelajaran. Tujuan pembelajaran yang dirumuskan yaitu: peserta didik dapat menjelaskan fenomena, merancang dan mengevaluasi percobaan serta menafsirkan dan menyimpulkan data secara ilmiah

\section{Tahap Design (Perancangan)}

Pada tahap ini dihasilkan prototype atau rancangan awal LKPD. Terdapat dua paket LKPD dimana setiap paket terdiri dari 2 macam faktor yang mempengaruhi Laju Reaksi. Tahapan dalam LKPD ini menyesuaikan tahap inkuiri terbimbing menurut National Research Council (2000) [18] dimana setiap tahapannya bertujuan untuk 
melatihkan keterampilan berpikir tingkat tinggi dengan tambahan basis belajar hands-on \& mindson activity.
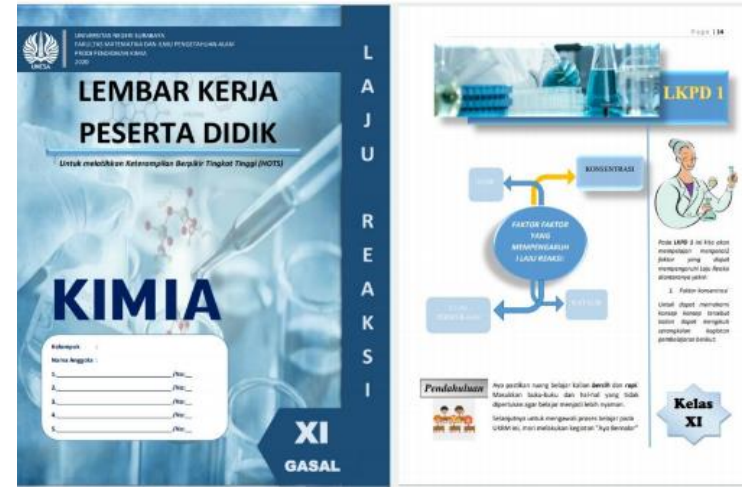

Gambar 1. Contoh Tampilan Cover LKPD utama dan Cover dalam

Pada cover LKPD utama ini di design dengan tampilan yang natural dan simple dimana hanya menampilkan judul materi (Laju Reaksi), jenjang sekolah, serta nama kelompok guna memudahkan ketika proses pengumpulan. Berbeda halnya dengan cover dalam yang hanya berisi peta konsep tentang faktor-faktor Laju Reaksi dan mengarahkan ke subtopik yang akan dibahas.

LKPD juga telah di design berdasarkan pembelajaran daring yang telah disesuaikan dengan pembelajaran model inkuiri berbasis hands-on \& minds-on. Aktivitas Hands on dalam LKPD ini ditunjukkan dalam kegiatan yang mencerminkan peserta didik dalam menggali pengetahuannya sendiri seperti kegiatan menganalisis serta mengumpulkan data kemudian menyimpulkan dengan pemahamannya sendiri. Data yang dikumpulkan disini adalah data hasil praktikum faktor-faktor yang mempengaruhi laju reaksi namun dalam era pembelajaran daring sehingga praktikum diganti dengan mengamati video percobaan melalui platform youtube yang telah_dipilihkan oleh peneliti. Kemudian untuk aktivitas Minds on dicerminkan melalui kegiatan dalam mengamati video, menulis rumusan masalah, hipotesis serta data-data hasil percobaan di dalam LKPD sebagai bentuk dari mengkomunikasikan data sehingga peserta didik dapat memperoleh penghayatan terhadap materi yang diajarkan dan dapat mengkonstruk pikirannya sendiri [9]. Seperti yang ditunjukkan pada Gambar 2 berikut:
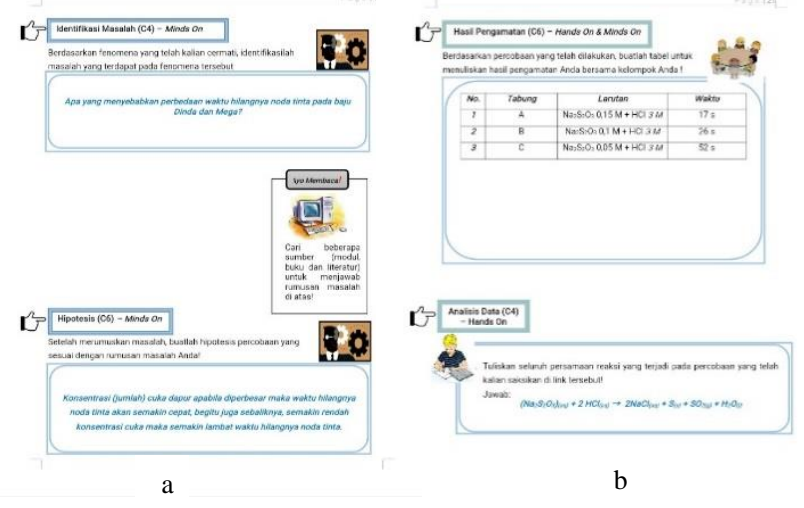

Gambar 2. Contoh Tampilan bagian dalam LKPD

\section{(a) Aktivitas minds-on activity, (b)Aktivitas hands-on activity}

\section{Tahap Develop (Pengembangan)}

Pada tahap Develop ini hasil yang didapat adalah seperangkat bahan ajar yang sudah diperbaiki berdasarkan hasil telaah dan validasi oleh para dosen dan 1 guru kimia. Proses yang dilakukan pertama kali yakni telaah LKPD, dimana hasil telaah tersebut dianalisis secara kualitatif sehingga didapatkan saran-saran yang bertujuan untuk memperbaiki LKPD. Saran-saran yang didapat selama proses telaah adalah saran mengenai perbaikan tata kalimat, kejelasan dan keefektifan kata, serta kebenaran makna pada peta konsep yang ada di LKPD. Dalam tahap pengembangan ini akan didapatkan kesimpulan mengenai kelayakan LKPD yang ditinjau dari aspek validitas, kepraktisan, dan keefektisan [14] . Peninjuan hal tersebut dilakukan guna mengembangkan LKPD yang sesuai dengan perkembangan peserta didik dan sesuai dengan kurikulum 2013 yang menuntuk keaktifan peserta $\operatorname{didik}[11]$.

\section{Validitas LKPD}

Selanjutnya yakni proses validasi LKPD, dimana hasilnya dianalisis secara kuantitatif. LKPD yang dikembangkan ini divalidasi oleh 2 orang dosen kimia serta 1 guru kimia SMAN 1 Krian. Nilai validitas LKPD yang dikembangkan ini ditinjau dari 4 komponen yakni validitas isi, penyajian, kebahasaan, dan kegrafisan. Kegiatan validasi ini sangat diperlukan guna perbaikan yang 
lebih mendalam pada LKPD yang akan dikembangkan sebelum nantinya akan diujicobakan secara terbatas. Berikut data hasil validasi:

\section{Tabel 7. Hasil Validasi LKPD}

\begin{tabular}{ccc}
\hline $\begin{array}{c}\text { Kriteria } \\
\text { yang dinilai }\end{array}$ & $\begin{array}{c}\text { Persentase } \\
\text { Rata-rata }(\boldsymbol{\%})\end{array}$ & Kategori \\
\hline Isi & 83 & Sangat Valid \\
Kebahasaan & 82 & Sangat Valid \\
Penyajian & 82 & Sangat Valid \\
Kegrafisan & 83 & Sangat Valid \\
\hline
\end{tabular}

Berdasarkan data Tabel 7, seluruh aspek validitas dinilai sangat valid karena berada pada rentang 81\%-100\%, dimana persentase tersebut sangat memenuhi kriteria atau dinyatakan valid ditinjau dari kriteria kevalidan isi menurut BSNP yang meliputi kesesuaian standar KD dan tujuan pembelajaran [19].

Validitas kriteria kebahasaan ini meliputi kompone-kompponen mengenai penggunaan istilah yang mudah dipahami, Bahasa Indonesia yang baik dan benar, serta menggunakan bahasa yang efektif dan efisien. Hal tersebut disesuaikan dengan usia anak dimana responden yang digunakan dalam penelitian ini rata-rata berusia 16-18 tahun dimana pada usia tersebut mereka berada pada tahap operasional formal sehingga disusunlah LKPD dengan istilah-istilah yang mudah dipahami. Validitas kebahasaan ini memperoleh nilai sesebesar $82 \%$ yang berarti bahwa LKPD dapat dikatakan sangat valid.

Selanjutnya LKPD juga dinilai sangat valid ditinjau dari kriteria kevalidan penyajian karena persentase nilai yang didapat berada pada rentang $81 \%-100 \%$. Kriteria penyajian dalam LKPD harus disajikan secara konsisten, konsep yang runtun, alenia yang runtun, serta kebutuhan makna yang sesuai [20].

Begitu pula dengan validitas LKPD dari kriteria kegrafisan dengan komponen-komponen yang meliputi cover yang menarik dan mempresentasikan isi LKPD, huruf dan ukuran font yang memudahkan pembaca, keserasian tata letak teks dan gambar pada LKPD, serta keserasian ilustrasi, gambar, grafis dan foto. Hal ini sangat diperlukan, karena LKPD yang dikembangkan juga perlu kiranya untuk meningkatkan minat peserta didik agar nantinya dapat terlibat aktif dalam pembelajaran. Nilai dari keseluruhan validasi penyajian ini mendapatkan nilai sebesar 83\% yang berarti bahwa LKPD dapat dikatakan sangat valid.

\section{Kepraktisan LKPD}

Kepraktisan LKPD ini dinilai berdasarkan angket respon yang diisi oleh peserta didik berdasarkan LKPD yang diberikan. Angket respon ini diberikan secara online melalui aplikasi google form dengan jangka waktu pengerjaan yang sama. Berikut persentase data hasil respon peserta didik:

Tabel 8. Hasil Angket Respon Peserta Didik

\begin{tabular}{ccc}
\hline $\begin{array}{c}\text { Aspek yang } \\
\text { dinilai }\end{array}$ & $\begin{array}{c}\text { Persentase } \\
\text { Rata-rata } \\
\mathbf{( \% )}\end{array}$ & Kategori \\
\hline Isi & 93,3 & Sangat Merespon \\
Kebahasaan & 91,7 & Sangat Merespon \\
Penyajian & 91.7 & Sangat Merespon \\
Kegrafisan & 86,1 & Sangat Merespon \\
\hline
\end{tabular}

Berdasarkan data pada Tabel 8 tersebut menunjukkan bahwa LKPD yang dikembangkan telah memenuhi kriteria kepraktisan pada setiap komponennya, hal ini dikarenakan persentase nilai yang diperoleh sudah berada pada rentang 86,193,3\% yang berarti mendapatkan respon yang sangat positif.

Berdasarkan data pada Tabel 8, komponen yang mendapat persentase nilai terendah adalah komponen kegrafisan, sehingga dapat ditarik kesimpulan bahwa peserta didik masih kurang termotivasi atau kurang merasa senang terhadap tampilan atau design grafis dari LKPD baik cover, jenis font, atau lainnya. Namun pada nilai validitas kegrafisan nilai yang didapatkan adalah sebesar $83 \%$ dengan kategori sangat valid.

\section{Keefektifan LKPD}

Keefektifan LKPD yang dikembangkan ini dapat ditentukan dari sejauh mana peserta didik dapat memahami konsep faktor-faktor laju reaksi yang diajarkan dengan bahan ajar berupa LKPD yang dikembangan. Pemahaman peserta didik tersebut dapat dideskripsikan melalui data ketuntasan klasikal tes hasil belajar ranah pengetahuan serta peningkatan HOTS peserta didik. Tes kognitif serta HOTS ini dilaksanakan 
secara online menggunakan aplikasi google form secara serentak di rumah masing-masing individu.

Hasil belajar ranah pengetahuan dinyatakan tuntas apabila nilai minimal yang didapatkan $\geq 75$ yang merupakan KKM di SMAN $1 \mathrm{Krian}$. Tes hasil belajar ini dilaksanakan setelah pembelajaran Laju Reaksi setelah LKPD yang dikembangkan selesai. Tes ini terdiri dari 10 butir soal pilihan ganda yang mencakup keempat faktor yang mempengaruhi laju reaksi. Hasil belajar ranah pengetahuan peserta didik ini kemudian diolah secara kuantitatif dan didapatkan rata-rata sebesar 85 dan mendapat ketuntasan klasikal sebesar $100 \%$.

Pemahaman peserta didik selanjutnya juga dapat dilihat dari peningkatan HOTS seperti gambar berikut:

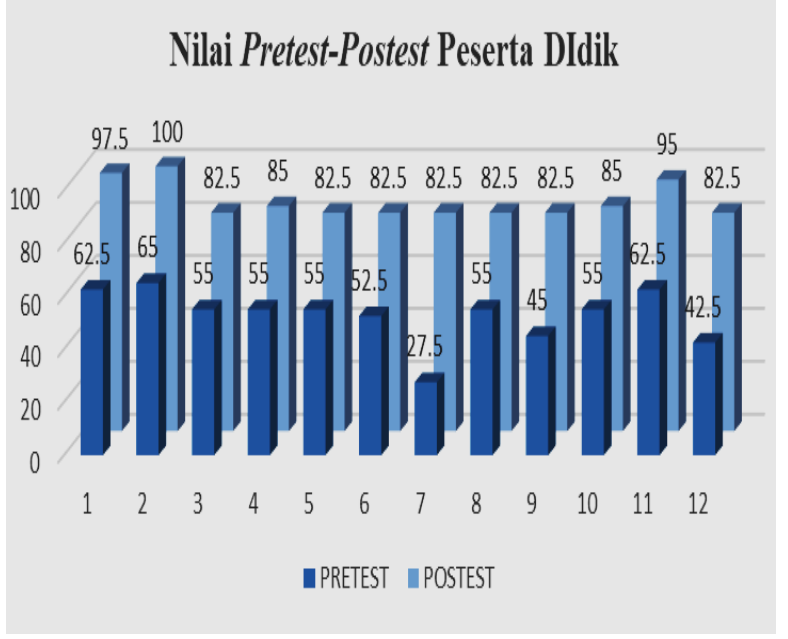

\section{Gambar 3. Grafik Peningkatan Nilai Pretest dan} Postetst

Berdasarkan gambar 3 tersebut dapat diketahui bahwa terdapat peningkatan HOTS peserta didik dari sebelum dan sesudah LKPD yang dikembangkan oleh peneliti sudah digunakan disekolah, dimana rata-rata nilai pretest adalah sebesar 52,7 dan rata-rata nilai posttest yang didapatkan adalah 86,7. HOTS peserta didik dikatakan telah terlatih apabila mendapat rata-rata $n$-gain $\geq 0,7$. Pada penelitian ini, rata-rata $n$-gain yang didapatkan adalah sebesar 0,73 dengan kategori tinggi. Hal ini menunjukkan bahwa LKPD yang dikembangkan efektif untuk melatihkan HOTS pada materi Laju Reaksi. Selanjutnya untuk hasil dari setiap ranah kognitif peserta didik didapatkan hasil yang dicantumkan dalam tabel berikut:

Tabel 9. Rata-Rata ranah kognitif Postest HOTS

\begin{tabular}{ccc}
\hline Aspek Kognitif & $\begin{array}{c}\text { Persentase } \\
\text { Rata-rata } \\
(\boldsymbol{\%})\end{array}$ & Kategori \\
\hline C4 (Menganalisis & 86,8 & Tinggi \\
C5 (Mengevaluasi) & 83,3 & Tinggi \\
C6 (Mencipta) & 87,5 & Tinggi \\
\hline
\end{tabular}

Berdasarkan data nilai ranah pengetahuan dan peningkatan HOTS yang telah dipaparkan diatas dapat disimpulkan bahwa LKPD inkuiri berbasis hands-on \& minds-on activity yang dikembangkan dapat dikatakan efektif karena memperoleh ketuntasan klasikal sebesar 100\% serta $n$-gain dari peningkatan HOTS sebesar 0,73. Hal ini sejalan dengan penelitian Aulia (2015) [12] dan Kurniawan, dkk (2017) [9] yang menunjukkan bahwa LKPD yang dikembangkan ini layak dikembangkan karena telah memenuhi kriteria valid, praktis, dan efektif sehingga layak digunakan untuk meningkatkan HOTS peserta didik. Dengan meningkatnya Keterampilan Berpikir Tingkat Tinggi ini maka tujuan kurikulum 2013 yang mengharuskan siswanya untuk berperilaku aktif dan analitis sehingga dapat memiliki kemampuan untuk pemecahan suatu masalah dapat tercapai [5].

\section{SIMPULAN}

Berdasarkan pembahasan data hasil penelitian, didapatkan kesimpulan bahwa LKPD yang dikembangkan layak digunakan dengan rincian sbagai berikut:

1. Hasil validasi untuk kriteria isi, kebahasaan, penyajian, dan kegrafisan menunjukkan persentase berturut-turut sebesar 83\%, 82\%, $82 \%$, dan $83 \%$ dengan kategori sangat valid.

2. Hasil angket respon peserta didik terhadap LKPD ditinjau dari kriteria isi, kebahasaan, penyajian, dan kegrafisan memperoleh persentase yang cukup tinggi dengan rata-rata 90,7\% yang menunjukkan sangat praktis.

3. Keefektifan LKPD dilihat melalui ketuntasan hasil belajar yang memperoleh persentase sebesar $100 \%$ dengan kategori tuntas dan skor 
$\mathrm{N}$-gain rata-rata 0,73 dengan kategori tinggi. Dimana dalam setiap komponen HOTS C4,C5, dan C6 didapatkan rata-rata persentase berturut-turut sebesar $86,8 \%, 83,3 \%$,dan $87,5 \%$.

\section{DAFTAR PUSTAKA}

1. Susilo, S.V., Prasetyo, T.F. 2020. Bahan Ajar Mobile Learning 2D Berbasis Android: Sebuah Pembelajaran Berbasis Teknologi Dalam Menghadapi Revolusi Industri 4.0. Jurnal Kajian Penelitian dan Pendidikan dan Pembelajaran. Vol. 4, No. 2b, pp. 587-592.

2. OECD. 2019. PISA 2018 Insight and Interpretation. New York: Columbia University.

3. Santra, P., Wibawa, I M., Rati, N.W. 2017. Pengaruh Model Pembelajaran Think Pair Share Berbantuan Power Point Terhadap Hasil Belajar Ipa. International Journal of Elementary education, Vol. 2, No.1, pp. 307-315.

4. Kurniaman, O., Noviana, E. 2017. Penerapan Kurikulum 2013 dalam Meningkatkan Keterampilan, Sikap, dan Pengetahuan. Jurnal Primary Program Studi Pendidikan Guru Sekolah Dasar Fakultas Keguruan dan Ilmu Pendidikan, Vol. 6, No. 2 pp. 389-396.

5. Brookhart, S.M. 2010, How To Asses HigherOrder Thinking Skills In Ypur Classroom. United States of America: ASCD Member Book.

6. Yuliandri, N., Hamdu, G., \& Respati, R. 2019. Pengembangan Soal Tes Berbasis Higher Order Thinking Skill (HOTS) Taksonomi Bloom Revisi di Sekolah Dasar. Jurnal Ilmiah Pendidikan Guru Sekolah Dasar, Vol 6, No. 1, pp. 37-46.

7. Kemendikbud. 2016. Permendikbud Nomor 24 Tahun 2016 Tentang Kompetensi Inti dan Kompetensi Dasar Kurikulum 2013 pada
Pendidikan Dasar dan Menengah. Jakarta: Kementerian Pendidikan dan Kebudayaan

8. Kemendikbud. 2020. Kepmendikbud Nomor 719/P/2020 tentang Pedoman

Pelaksanaan Kurikulum pada Satuan Pendidikan dalam Kondisi Khusus pada Pendidikan Dasar dan Menengah. Jakarta: Kementerian Pendidikan dan Kebudayaan

9. Kurniawa, W., Erikanto, C., Suana., W. 2017. Pengaruh Hands On Minds On Activity Terhadap Hasil Belajar Melalui Inkuiri Terbimbing. Jurnal Pembelajaran Fisika. Vol. 5, No. 2, pp. 105-116.

10. Handarini, O.I. 2020. Pembelajaran Daring Sebagai Upaya Study From Home (SFH) Selama Pandemi Covid 19. Jurnal Pendidikan Administrasi Perkantoran,. Vol. 8, No. 3, pp. 496-503.

11. Lestari, L., Alberida, H., Rahmi, Y.L. 2018. Validitas dan Praktikalitas Lembar Kerja Peserta Didik (LKPD) Materi Kingdom Plantae Berbasis Pendekatan Saintifik untuk Peserta Didik Kelas X SMA/MA. Jurnal Eksakta Pendidikan (JEP), Vol. 2, No. 2, pp. 170-177

12. Aulia, E.V., Ismono. 2015. Pengembangan Lembar Kegiatan Siswa (LKS) Berorientasi Inkuiri untuk Melatihkan Keterampilan Berpikir Tingkat Tinggi Siswa pada Materi Ikatan Kimia Kelas X SMA WIDYA DARMA SURABAYA. UNESA Journal of Chemical Education, Vol. 4, No.2, pp. 163-171.

13. Jamilah, S., \& Kamaludin, A. 2019. Pengembangan Buku Panduan Pendidik Berorientasi Chemo-Enterpreneurship (CEP) pada materi Ikatan Kimia SMA/MA Kelas X. Jurnal Pendidikan Sains (JPS), Vol. 7, No.1, pp. 36-46.

14. Fatmawati, A. 2016. Pengembangan Perangkat Pembelajaran Konsep Pencemaran Lingkungan Menggunakan Model 
Pembelajaran Berdasarkan Msalah untuk SMA Kelas X. Jurnal EduSains, Vol.4, No.2, pp. 94-103.

15. Riduwan dan Sunarto. 2017. Pengantar Statistika untuk Penelitian: Pendidikan, Sosial, Komunikasi, Ekonomi, dan Bisnis. Bandung: Alfabeta.

16. Hake R R. 1999. Interactive Engagement versus Traditional Methods: A Six Thousand Student Survey of Mechanics Test Data for Introductory Physics Courses. American Journal Physics, Vol. 66, No. 1, pp 64-74.

17. Ain, Q., Mitarlis. 2020. Pengembangan LKPD Berorientasi inkuiri Terbimbing untuk Meningkatkan Literasi Sains pada Materi
Faktor-Faktor yang Mempengaruhi Laju Reaksi. UNESA Journal of Chemical Education, Vol. 9, No. 3, pp. 397-406.

18. National Research Council. 2000. Inquiry and the National Science Education Standards: A Guide for Teaching and Learning/Center for Science,Matematics, and Engineering Education. US America: National Academi of Sciences.

19. BSNP. 2010. Paradigma Pendidikan Nasional Abad-XXI. Jakarta: BSNP.

20. Depdiknas. 2008. Pengembangan Bahan Ajar. Direktorat Pembinaan Sekolah Menengah Atas Direktorat Jenderal Manajemen Pendidikan Dasar dan Menengah Departemen Pendidikan Nasional. 